\title{
Studies on the Genotoxicity Behavior of Silver Nanoparticles in the Presence of Heavy Metal Cadmium Chloride in Mice
}

\author{
Hanan Ramadan Hamad Mohamed \\ Zoology Department, Faculty of Science, Cairo University, Giza, Egypt \\ Correspondence should be addressed to Hanan Ramadan Hamad Mohamed; hananeeyra@gmail.com
}

Received 16 May 2016; Revised 20 July 2016; Accepted 10 August 2016

Academic Editor: Piersandro Pallavicini

Copyright ( 2016 Hanan Ramadan Hamad Mohamed. This is an open access article distributed under the Creative Commons Attribution License, which permits unrestricted use, distribution, and reproduction in any medium, provided the original work is properly cited.

\begin{abstract}
Incredible rapid growth in the nanoparticles applications and development increases the daily human exposure to them but humans are exposed to many other pollutants in addition to nanoparticles that forced us to evaluate the effect of heavy metal cadmium chloride $\left(\mathrm{CdCl}_{2}\right)$ coinjection on silver nanoparticles induced genotoxic risk in this study. Mice were injected into the abdominal cavity with single dose of Ag nanoparticles $\left(20,41\right.$, and $82 \mathrm{mg} / \mathrm{kg}$ ) or $\mathrm{CdCl}_{2}(1.5 \mathrm{mg} / \mathrm{kg})$ either separately or together simultaneously and sacrificed 24 hours later. $\mathrm{CdCl}_{2}$ cotreatment enhanced the induced dose-dependent sperm abnormality by Ag nanoparticles different doses as shown by the statistical significant decreases in both sperm concentration and motility and increases in the frequency of abnormal sperms and also potentiated the Ag nanoparticles induced chromosomal and DNA damage indicated by the statistical significant elevations in the frequencies of micronucleated polychromatic erythrocytes (MNPCEs) and DNA damage levels. Moreover, statistical elevations in malondialdehyde level and reductions in catalase activity were observed after $\mathrm{CdCl}_{2}$ coinjection with Ag nanoparticles compared with Ag nanoparticles treated groups' values. Ag nanoparticles induced sperm abnormality, clastogenicity, and genotoxicity were potentiated by heavy metal cadmium coinjection that threatens the human life and increases silver nanoparticles genotoxic risks.
\end{abstract}

\section{Background}

The last few years have seen an incredibly rapid growth in the use of nanomaterials such as metal nanomaterials in food, medicine, and industry, resulting in increasing human exposure to them. Silver (Ag) nanoparticles are one of the most commonly used metal nanoparticles in many consumer, medical, and industrial products such as water, toothpaste, shampoo, cosmetics, filters, kitchen utensils, toys, and food because of their characteristic antibacterial activity [1-4].

However, the extensive uses of Ag nanoparticles caused several negative health effects including hepatotoxicity, neurotoxicity, nephrotoxicity, and genotoxicity [5-7]. Genotoxicity and cytotoxicity of $\mathrm{Ag}$ nanoparticles have been evidenced in both in vitro and in vivo experimental systems. The inductions of chromosomal and DNA damage by Ag nanoparticles have been evidenced in several mammalian and fish cell [8-12]. Inductions of apoptosis and necrosis by these nanoparticles were also shown in the cultured $\mathrm{HeLa}$ cells and intestinal epithelial cells $[13,14]$.

The in vivo induced genetic damage by Ag nanoparticles has been shown in different experimental systems. Ag nanoparticles have been shown to induce chromosomal aberrations and micronuclei in rat bone marrow cells [15]. Using comet assay DNA damage induction by Ag nanoparticles was indicated by the significant elevations in both single and double strand DNA breaks in rats and mice [16, 17]. High levels of $\gamma$-H2AX (a marker for double DNA strand breaks) also evidenced DNA damage inductions in zebra fish orally given Ag nanoparticles [18]. Moreover, polysaccharide coated Ag nanoparticles elevated the DNA damage markers ( $p 53$ and p38 proteins) in Drosophila melanogaster [19].

The embryo-toxicity of Ag nanoparticles also has been shown by the reported congenital malformations, reductions in mice fetus viability, apoptosis in mouse embryos at the blastocyst stage, reduction of implantation frequency, and 
delay in postimplantation development of embryos [20-23]. Additionally, Ag nanoparticles have been shown to significantly reduce sperm counts and elevate the sperm abnormalities in mice and rats $[24,25]$.

In addition to these nanoparticles, there are many other substances to which humans are exposed directly or indirectly such as heavy metals. Cadmium (Cd) is one of the most important toxic environmental pollutants to which humans and animals are exposed because industrial and agricultural practices increase its level continuously in the environment [26]. Cd has been shown to induce micronuclei in polychromatic erythrocytes in both tibia bone marrow and peripheral blood in rats [27]. Also, the clastogenicity of $\mathrm{Cd}$ has been demonstrated by the development of chromosomal aberrations and sister chromatids exchanges [28, 29].

As previously shown the genotoxicity of either $\mathrm{Ag}$ nanoparticles or Cd was studied separately but the genotoxicity behavior of $\mathrm{Ag}$ nanoparticles combined with $\mathrm{Cd}$ was not studied until now in spite of human exposure to both $\mathrm{Ag}$ nanoparticles and $\mathrm{Cd}$ via contaminated air, drinking water, and even food. Therefore, the present study was designed to study the clastogenicity and genotoxicity of Ag nanoparticles in the presence of $\mathrm{Cd}$ in mice bone marrow, testes, and sperms. Micronucleus and comet assay were done to assess chromosomal and DNA damage, respectively. Sperm count, abnormality, and motility were also estimated to study the effect of Ag nanoparticles on sperm and thus on fertility.

\section{Materials and Methods}

2.1. Animals. Male Swiss Webster mice weighting 30-35 grams were obtained from the animal house of National Organization for Drug Control and Research (NODCAR). They were left in lab for one week under standard dark/light cycle to be acclimatized with the laboratory conditions and supplied with standard diet pellets and water that were given ad libitum. All experiments on animals were performed in accordance with The Institutional Animal Care and Use Committee (IACUC), Faculty of Science, Cairo University.

2.2. Chemicals. All chemicals were purchased from Sigma Aldrich Chemical Company. Cd was obtained in the form of white $\mathrm{CdCl}_{2}$ powder and dissolved in deionized water to prepare the selected injected dose $(1.5 \mathrm{mg} / \mathrm{kg})$ that represents $25 \%$ of the computed 24 -hour LD50 $(5.98 \mathrm{mg} / \mathrm{kg})$ in mice by the study of Ali [30]. While Ag nanoparticles were purchased in the form of grey nanopowder with size $<100 \mathrm{~nm}$, its purity was $99.5 \%$ and contains polyvinylpyrrolidone (PVP) as a dispersant. Ag nanoparticles were suspended in deionized distilled water to prepare the doses required to inject mice in both preliminary tests to detect their LD50 and the remaining experiments.

\subsection{Characterization of Ag Nanoparticles}

2.3.1. X-Ray Diffraction (XRD). Nano-Ag particles XRD patterns were measured using a charge coupled device diffractometer (XPERT-PRO, PANalytical, Netherlands). Using Scherrer's relationship $(D=0.9 k / B \cos h)$ particle size was calculated, where $k$ is the wavelength of $\mathrm{X}$-ray, $B$ is the broadening of diffraction line measured as half of its maximum intensity in radians, and $h$ is Bragg's diffraction angle. The particle size of sample has been estimated from the line width of XRD peak.

2.3.2. Dynamics Laser Scattering (DLS). Agglomeration size and zeta potential of Ag nanoparticles were detected by the routine work using Malvern Instrument Zetasizer Nano Series (Malvern Instruments, Westborough, MA) equipped with a He-Ne laser $(\lambda=633 \mathrm{~nm}$, $\max 5 \mathrm{~mW})$.

2.3.3. Transmission Electron Spectroscopy (TEM). After sonication of Ag nanoparticles suspensions in Milli-Q water at $40 \mathrm{~W}$ for $25 \mathrm{~min}$, drops of $\mathrm{Ag}$ suspensions were coated on carbon-coated copper TEM grids and dried, and finally TEM (a Tecnai G20, Super twin, double tilt) was operated at an accelerating voltage of $200 \mathrm{kV}$ to $\mathrm{Ag}$ nanoparticles and to detect their morphology and particle average size.

2.4. Determination of $\mathrm{Ag}$ LD50. The lethal dose of $\mathrm{Ag}$ nanoparticles that causes the death of $50 \%$ of the animals (LD50) was determined by injecting mice intraperitoneally (i.p.) with each of the six dose levels of Ag nanoparticles 500, $1500,2500,3500,4000$, or $5000 \mathrm{mg} / \mathrm{kg}$ b.w., five mice per each group. Each group was observed for mortality, body weight effects, and the clinical signs of toxicity and the number of dead mice was monitored during the first 24 hours. After that, the LD50 was calculated using the computer software EPA probit analysis by aid of NCSS package software, version 10, and the three fractions $(1 / 100,1 / 50$, and 1/25) of LD50 dose of Ag nanoparticles were tested in this study.

2.5. Treatment Schedule. Animals were divided randomly into eight groups of five animals each and injected i.p. First two groups were injected with distilled water (dist. $\mathrm{H}_{2} \mathrm{O}$ ) (negative control group) or $\mathrm{CdCl}_{2}$ at $1.5 \mathrm{mg} / \mathrm{kg}$ b.w. while the remaining six groups were injected with each of the three dose levels of Ag nanoparticles (20,41, and $82 \mathrm{mg} / \mathrm{kg}$ b.w.) either alone (groups 3,4 , and 5) or simultaneously with $\mathrm{CdCl}_{2}$ (groups 6, 7, and 8) and all groups were sacrificed 24 hours later.

2.6. Sperm Abnormality. Sperm abnormality was investigated by removing the cauda epididymides and cutting them into small pieces in Petri dish containing $2 \mathrm{~mL}$ saline. A small amount of sperm suspension was added to the cell counting hemocytometer plates and the total sperm number and motile sperm number were counted using a highmagnification microscope as described by Watanabe and Endo [31]. The sperm concentration and motility rate were calculated using the following equations:

$$
\begin{aligned}
& \text { Sperm concentration }=\text { the total sperm number } \div(4 \\
& \left.\quad \times 10^{4} \times 2\right)
\end{aligned}
$$

Sperm motility rate $=($ the motile sperm number

$$
\div \text { the total sperm number) } \times 100 \text {. }
$$


Indeed, a small amount of sperm suspension was drawn and smeared on a slide, fixed for $10 \mathrm{~min}$ with methanol, stained for 1 hour with $1 \%$ eosin, and then washed with water. A total of 1000 sperms were counted to determine the proportion of malformed sperm using a high-magnification microscope:

The sperm malformation rate

$$
=(\text { the malformed sperm number } \div 1000) \times 100 \text {. }
$$

2.7. Micronucleus Assay. To detect the chromosomal damage, micronucleus assay was performed on bone marrow according to the method described by Schmid [32]: femur bone marrow cells are flushed down, spread on clean slide, air-dried, fixed, and finally stained for $5 \mathrm{~min}$ in May-Grunwald-Giemsa stain mixture and then mounted with Distrene 80, Dibutyl Phthalate Xylene (DPX). Two thousand polychromatic erythrocytes per animal were scored to determine the number of micronucleated polychromatic erythrocytes (MNPCEs). Also, polychromatic to normochromatic erythrocytes ratio (PCEs/NCEs) was determined per 1000 cells.

2.8. Comet Assay. The alkaline comet assay was done to detect both single and double strand breaks in sperms, testes, and bone marrow cells. Bone marrow cells and sperms obtained from epididymis were suspended into mincing solution, while small piece of testis, about $50 \mathrm{mg}$, was homogenized gently into mincing solution. According to Tice et al. [33] method, about 10,000 cells were mixed with $75 \mu \mathrm{L}$ of $0.5 \%$ low melting point agarose (Sigma) and spread on a fully frosted slide predipped in normal melting agarose (1\%). After solidification, cells were lysed in cold lysis buffer (2.5 M NaCl, $100 \mathrm{mM}$ EDTA, and $10 \mathrm{mM}$ Tris, $\mathrm{pH}$ 10) with freshly added $10 \%$ DMSO and $1 \%$ Triton X-100 for $24 \mathrm{~h}$ at $4^{\circ} \mathrm{C}$ in dark. Subsequently, the slides were incubated in fresh alkaline buffer (300 mM NaOH and $1 \mathrm{mM}$ EDTA, pH 13) for $20 \mathrm{~min}$. The unwinding DNA was electrophoresed for $20 \mathrm{~min}$ at $300 \mathrm{~mA}$ and $25 \mathrm{~V}(0.90 \mathrm{~V} / \mathrm{cm})$ and neutralized in $0.4 \mathrm{M}$ Trizma base ( $\mathrm{pH} 7.5$ ) and, finally, fixed in 100\% cold ethanol, air-dried, and stored at room temperature until cells were scored. The extent of DNA migration for each sample was determined by simultaneous image capture and scoring of 100 cells stained with ethidium bromide at $\times 400$ magnification using Komet 5 image analysis software developed by Kinetic Imaging, Ltd. (Liverpool, UK). The extent of DNA damage was evaluated using tail length, $\%$ tail DNA, and tail moment as DNA damage endpoints.

\subsection{Malondialdehyde Level and Catalase Activity Measure-} ment. In this study biochemical evaluation of malondialdehyde (MDA) level (marker of lipid peroxidation) and the antioxidant catalase (CAT) activity was done in bone marrow, testis, and epididymal sperms of all groups. According to the method described by Ohkawa et al. [34], the MDA level was determined by reacting the thiobarbituric acid (TBA) substance with MDA in acidic medium at temperature of $95^{\circ} \mathrm{C}$ for $30 \mathrm{~min}$ to form $\mathrm{TBA}$ reactive product and the absorbance of the resultant pink product was measured spectrophotometrically at $534 \mathrm{~nm}$. Results were expressed as $\mathrm{nmol} / \mathrm{g}$ tissue used for bone marrow and testis and as $\mathrm{nmol} / 10^{6}$ sperms for epididymal sperms.

On the other hand, CAT activity was measured using the method described by Aebi [35] that showed that CAT reacts with a known quantity of $\mathrm{H}_{2} \mathrm{O}_{2}$. The reaction is stopped after exactly $1 \mathrm{~min}$ with CAT inhibitor. In the presence of peroxidase, the remaining $\mathrm{H}_{2} \mathrm{O}_{2}$ reacts with 3,5-dichloro2-hydroxybenzene sulfonic acid and 4-aminophenazone to form a chromophore with color intensity inversely proportional to the amount of CAT in the original sample. Results were expressed as U/g tissue used for bone marrow and testis and as $\mathrm{U} / 10^{6}$ sperms for epididymal sperms.

2.10. Statistical Analysis. Using the statistical software package SPSS 21 all data were analyzed at the significant level $<0.05$ by the independent sample $t$-test to test differences between each of the treated groups and the negative control group. One way analysis of variance (ANOVA) and regressions analysis curves were also used to test effect of Ag nanoparticles dose on the tested parameters.

\section{Results}

3.1. Characteristic of Ag Nanoparticles. Results of Ag nanoparticles characterization were summarized in Figure 1. The appearance of peaks at $44^{\circ}, 64.4^{\circ}$, and $77^{\circ}$ in XRD analysis curve confirmed the purchased form of $\mathrm{Ag}$ nanoparticles (Figure 1(a)) and by using Debye Scherrer's formula their nanocrystal size was confirmed and found to range from 20.8 to $27.7 \mathrm{~nm}$. The zeta potential mean was $9.35 \mathrm{mV}$ and the polydispersity index (PdI) as synonym to agglomeration size was 1 that indicated the high aggregation and agglomeration capacity of Ag nanoparticles in dist. deionized $\mathrm{H}_{2} \mathrm{O}$ (Figures 1(b) and 1(c)). Indeed, TEM imaging of the ultrasonicated Ag nanoparticles showed their cubic structure increasing its surface area and its activity and confirmed the nanosize of Ag nanoparticles $(56.67 \pm 9.77 \mathrm{~nm})$ in spite of presence of small agglomerates (Figure 1(d)).

3.2. LD50 of Ag Nanoparticles. Signs of mortality were observed on mice injected i.p. by the different doses of $\mathrm{Ag}$ nanoparticles $(500,1500,2500,3500,4000$, or $5000 \mathrm{mg} / \mathrm{kg}$ b.w.) including weakness, decreased motor activity, convulsions, abdominal swelling, and hind limbs paralysis. Using the probit analysis software, the 24 hours' lethality doses (from LD1 to LD99) of Ag nanoparticles were calculated and summarized in Table 1. As LD50 were found to be about $2056 \mathrm{mg} / \mathrm{kg}$ b.w., the tested three fractions of $(1 / 100,1 / 50$, and 1/25) LD50 in this study were 20, 41, and $82 \mathrm{mg} / \mathrm{kg}$ b.w., respectively.

3.3. Sperm Abnormality. As shown in Table 2, groups treated with either $\mathrm{CdCl}_{2}(1.5 \mathrm{mg} / \mathrm{kg})$ or Ag nanoparticles $(20,41$, and $82 \mathrm{mg} / \mathrm{kg}$ ) alone induced sperm abnormality as shown by the statistical significant increases $(p<0.001)$ in frequency of abnormal sperms and decreases $(p<0.001)$ in both sperm concentrations and sperm motility compared with the negative control group. On the other hand, simultaneous 


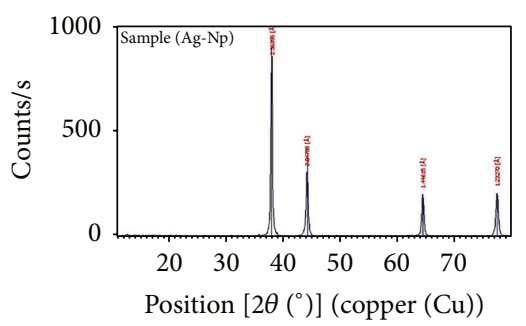

(a) XRD analysis

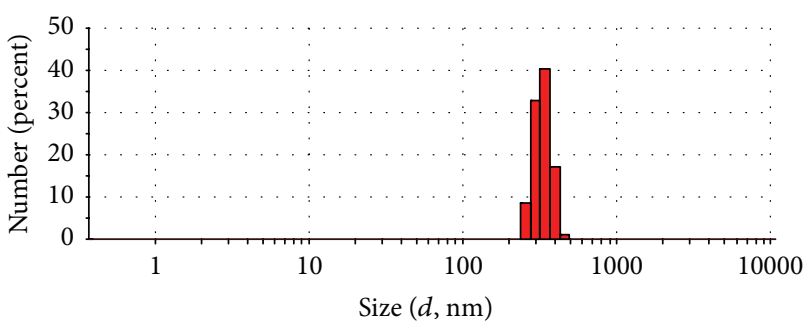

(b) Size distribution by number

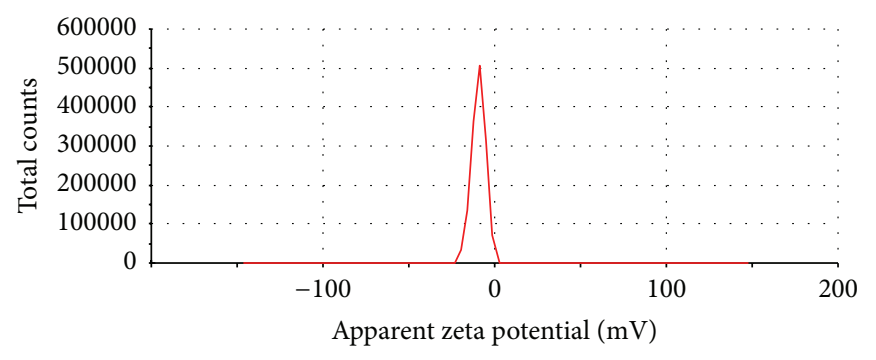

(c) Zeta potential distribution

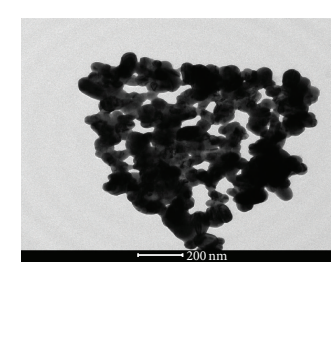

(d) TEM image of Ag nanoparticles

Figure 1: Characterization of Ag nanoparticles.

TABLE 1: The computed 24-hour lethality doses of Ag nanoparticles injected i.p. in male mice.

\begin{tabular}{lcc}
\hline Percentile & Probit & $\begin{array}{c}\text { Dose }(\mathrm{mg} / \mathrm{kg}) \\
\text { Mean } \pm \text { SE }\end{array}$ \\
\hline 1 & 2.6737 & $377.31 \pm 266.47$ \\
5 & 3.3551 & $620.03 \pm 335.51$ \\
10 & 3.7184 & $808.01 \pm 368.37$ \\
20 & 4.1584 & $1113.45 \pm 398.48$ \\
25 & 4.3255 & $1257.69 \pm 406.39$ \\
30 & 4.4756 & $1403.09 \pm 412.11$ \\
40 & 4.7467 & $1709.56 \pm 422.15$ \\
50 & 5.0000 & $2056.26 \pm 441.17$ \\
60 & 5.2533 & $2473.28 \pm 491.44$ \\
70 & 5.5244 & $3013.51 \pm 615.91$ \\
75 & 5.6745 & $3361.88 \pm 730.21$ \\
80 & 5.8416 & $3797.40 \pm 903.93$ \\
90 & 6.2816 & $5232.89 \pm 1647.36$ \\
95 & 6.6449 & $6819.33 \pm 2669.52$ \\
99 & 7.3263 & $11206.31 \pm 6152.05$ \\
\hline
\end{tabular}

injection of $\mathrm{CdCl}_{2}$ with $\mathrm{Ag}$ nanoparticles different doses enhanced the Ag nanoparticles induced sperm abnormality by the statistical significant increases in frequency in abnormal sperm and decreases in sperm concentrations and sperm motility (groups 6, 7, and 8) compared with those in groups treated with Ag nanoparticles alone (groups 3, 4, and 5). Representative photo for the observed abnormal sperms was shown in Figure 2.

One way ANOVA analysis showed that the dose of Ag nanoparticles caused statistical significant changes $(p<0.001)$ in

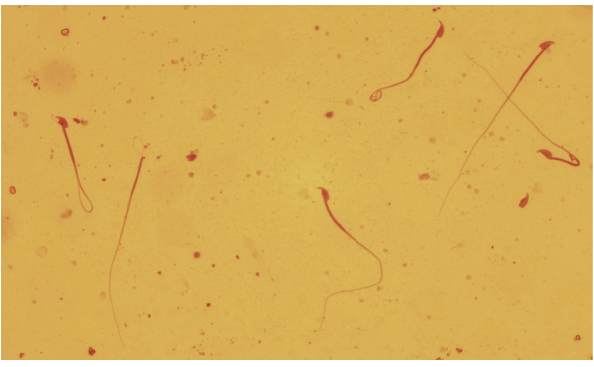

FIgURE 2: Representative photo for the observed abnormal sperms.

sperm concentration, sperm motility, and abnormal sperms frequency. Moreover, regression analysis curves indicated strong negative and positive correlations between both sperm concentration and motility and abnormal sperm frequency, respectively, and the different doses of $\mathrm{Ag}$ nanoparticles in both groups received Ag nanoparticles either alone or with Cd (Table 2, Figure 3).

3.4. Results of Micronucleus Assay. Chromosomal damage induction was estimated in this study by the frequency of micronucleated polychromatic erythrocytes (MNPCEs/1000 PCEs). Statistical significant elevations in the MNPCEs frequencies $(p<0.001)$ were induced in groups treated with either $\mathrm{CdCl}_{2}(1.5 \mathrm{mg} / \mathrm{kg})$ or $\mathrm{Ag}$ nanoparticles $(20,41$, and $82 \mathrm{mg} / \mathrm{kg}$ ) compared with the negative control (Table 3). Moreover, $\mathrm{CdCl}_{2}$ cotreatment with the different doses of $\mathrm{Ag}$ nanoparticles resulted in statistical significant elevations in the MNPCEs frequencies compared with Ag nanoparticles treated groups (Table 3 ).

Also, administration of either $\mathrm{Cd}$ or Ag nanoparticles alone resulted in statistical significant decreases $(p<0.001)$ in the percentage of polychromatic erythrocytes (\% PCEs) 
TABLE 2: Sperm concentrations, sperm motility, and abnormal sperms frequency in mice injected i.p. with $\mathrm{Ag}$ nanoparticles or/and $\mathrm{CaCl}_{2}$.

\begin{tabular}{|c|c|c|c|c|}
\hline Group & $\begin{array}{c}\text { Treatment } \\
(\text { dose } \mathrm{mg} / \mathrm{kg})\end{array}$ & $\begin{array}{c}\text { Sperm concentration } \\
\left(10^{6} / \mathrm{mL}\right)\end{array}$ & Sperm motility (\%) & Abnormal sperms (\%) \\
\hline 1 & Negative control & $1.44 \pm 0.04$ & $77.04 \pm 1.68$ & $5.20 \pm 1.30$ \\
\hline 2 & $\mathrm{Cd}_{(1.6)}$ & $0.58 \pm 0.15^{\mathrm{a}}$ & $29.63 \pm 3.26^{\mathrm{a}}$ & $58.20 \pm 4.66^{\mathrm{a}}$ \\
\hline 3 & $\mathrm{Ag}_{(20)}$ & $1.18 \pm 0.06^{\mathrm{a}}$ & $55.09 \pm 3.55^{\mathrm{a}}$ & $18.40 \pm 3.21^{\mathrm{a}}$ \\
\hline 4 & $\mathrm{Ag}_{(41)}$ & $0.92 \pm 0.07^{\mathrm{a}}$ & $30.44 \pm 2.48^{\mathrm{a}}$ & $37.6 \pm 2.30^{\mathrm{a}}$ \\
\hline 5 & $\mathrm{Ag}_{(82)}$ & $0.45 \pm 0.05^{\mathrm{a}}$ & $21.92 \pm 2.05^{\mathrm{a}}$ & $59.00 \pm 2.24^{\mathrm{a}}$ \\
\hline 6 & $\mathrm{Ag}_{(20)}+\mathrm{Cd}$ & $0.98 \pm 0.05^{\mathrm{a}, \mathrm{b} * * *}$ & $35.47 \pm 2.63^{\mathrm{a}, \mathrm{b} * * *}$ & $31.20 \pm 2.38^{\mathrm{a}, \mathrm{b} * * *}$ \\
\hline 7 & $\mathrm{Ag}_{(41)}+\mathrm{Cd}$ & $0.70 \pm 0.08^{\mathrm{a}, \mathrm{b} * *}$ & $23.86 \pm 2.96^{\mathrm{a}, \mathrm{b} * *}$ & $52.20 \pm 2.59^{\mathrm{a}, \mathrm{b} * * *}$ \\
\hline \multirow[t]{3}{*}{8} & $\mathrm{Ag}_{(82)}+\mathrm{Cd}$ & $0.36 \pm 0.04^{\mathrm{a}, \mathrm{b} * *}$ & $10.71 \pm 1.72^{\mathrm{a}, \mathrm{b} * * *}$ & $74.60 \pm 4.56^{\mathrm{a}, \mathrm{b} * * *}$ \\
\hline & Groups 3,4 , and 5 & $F=194, p<0.001$ & $F=193, p<0.001$ & $F=300, p<0.001$ \\
\hline & Groups 6,7 , and 8 & $F=137, p<0.001$ & $F=124, p<0.001$ & $F=216, p<0.001$ \\
\hline
\end{tabular}

Results were expressed as mean \pm SD. ${ }^{\text {a }}$ Statistically significantly different from the negative control group at $p<0.001$ and ${ }^{\mathrm{b}}$ statistically significantly different from the comparable nano-Ag treated group at ${ }^{* *} p<0.01$ and ${ }^{* * *} p<0.001$, respectively, using Student's $t$-test. One way ANOVA was used to test the effect of different doses of $\mathrm{Ag}$ nanoparticles on the tested parameters.
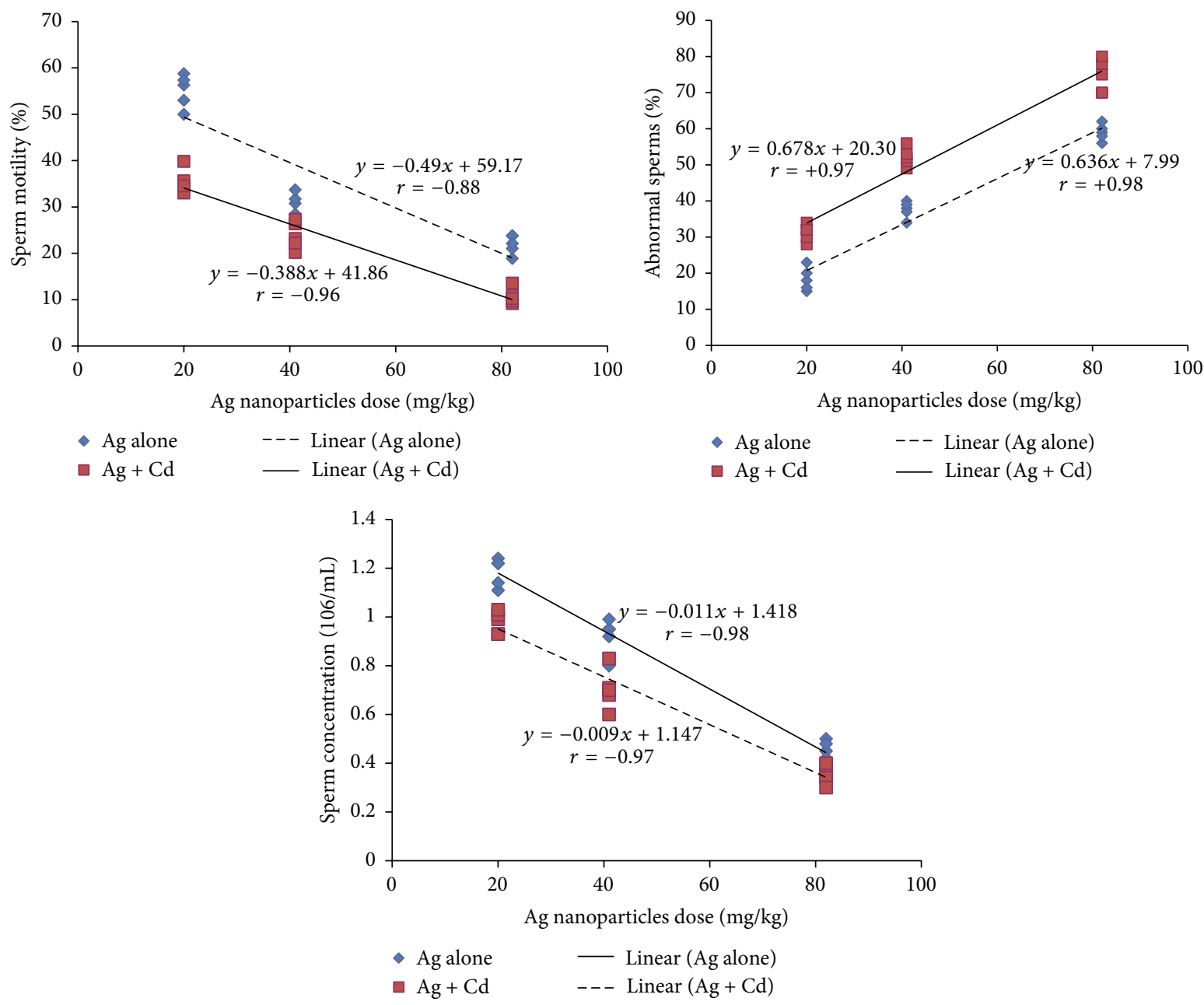

FIGURE 3: Regression lines and correlation coefficients between sperm concentrations, sperm motility, or frequency of abnormal sperms and the different doses of Ag nanoparticles in mice injected i.p. with $\mathrm{Ag}$ nanoparticles either alone or with $\mathrm{CaCl}_{2}$. 
TABLE 3: The MNPCEs frequencies and PCEs percentage in mice injected i.p. with Ag nanoparticles or/and $\mathrm{CaCl}_{2}$.

\begin{tabular}{lccc}
\hline Group & Treatment (dose mg/kg) & MNPCEs/1000 cells & \% PCEs \\
\hline 1 & Negative control & $5.20 \pm 2.17$ & $49.80 \pm 1.48$ \\
2 & $\mathrm{Cd}_{(1.6)}$ & $47.60 \pm 3.36^{\mathrm{a}}$ & $35.80 \pm 2.39^{\mathrm{a}}$ \\
3 & $\operatorname{Ag}_{(20)}$ & $47.20 \pm 2.17^{\mathrm{a}}$ & $41.80 \pm 1.30^{\mathrm{a}}$ \\
4 & $\mathrm{Ag}_{(41)}$ & $73.60 \pm 6.02^{\mathrm{a}}$ & $30.60 \pm 2.41^{\mathrm{a}}$ \\
5 & $\mathrm{Ag}_{(82)}$ & $94.40 \pm 5.94^{\mathrm{a}}$ & $22.20 \pm 3.81^{\mathrm{a}}$ \\
6 & $\mathrm{Ag}_{(20)}+\mathrm{Cd}$ & $73.60 \pm 6.65^{\mathrm{a}, \mathrm{b} * * *}$ & $36.20 \pm 2.77^{\mathrm{a}, \mathrm{b} * *}$ \\
7 & $\mathrm{Ag}_{(41)}+\mathrm{Cd}$ & $104.60 \pm 5.73^{\mathrm{a}, \mathrm{b} * *}$ & $25.80 \pm 1.92^{\mathrm{a}, \mathrm{b} * * *}$ \\
8 & $\mathrm{Ag}_{(82)}+\mathrm{Cd}$ & $144.60 \pm 5.73^{\mathrm{a}, \mathrm{b} * *}$ & $17.40 \pm 1.14^{\mathrm{a}, \mathrm{b} * * *}$ \\
\hline & Groups 3, 4 , and 5 & $F=105, p<0.001$ & $F=173, p<0.001$ \\
& Groups 6, 7, and 8 & $F=149, p<0.001$ & $F=110, p<0.001$ \\
\hline
\end{tabular}

Results were expressed as mean \pm SD. ${ }^{a}$ Statistically significantly different from the negative control group at $p<0.001$ and ${ }^{\text {b }}$ statistically significantly different from the comparable nano-Ag treated group at ${ }^{* *} p<0.01$ and ${ }^{* * *} p<0.001$, respectively, using Student's $t$-test. One way ANOVA was used to test the effect of different doses of Ag nanoparticles on the tested parameters.
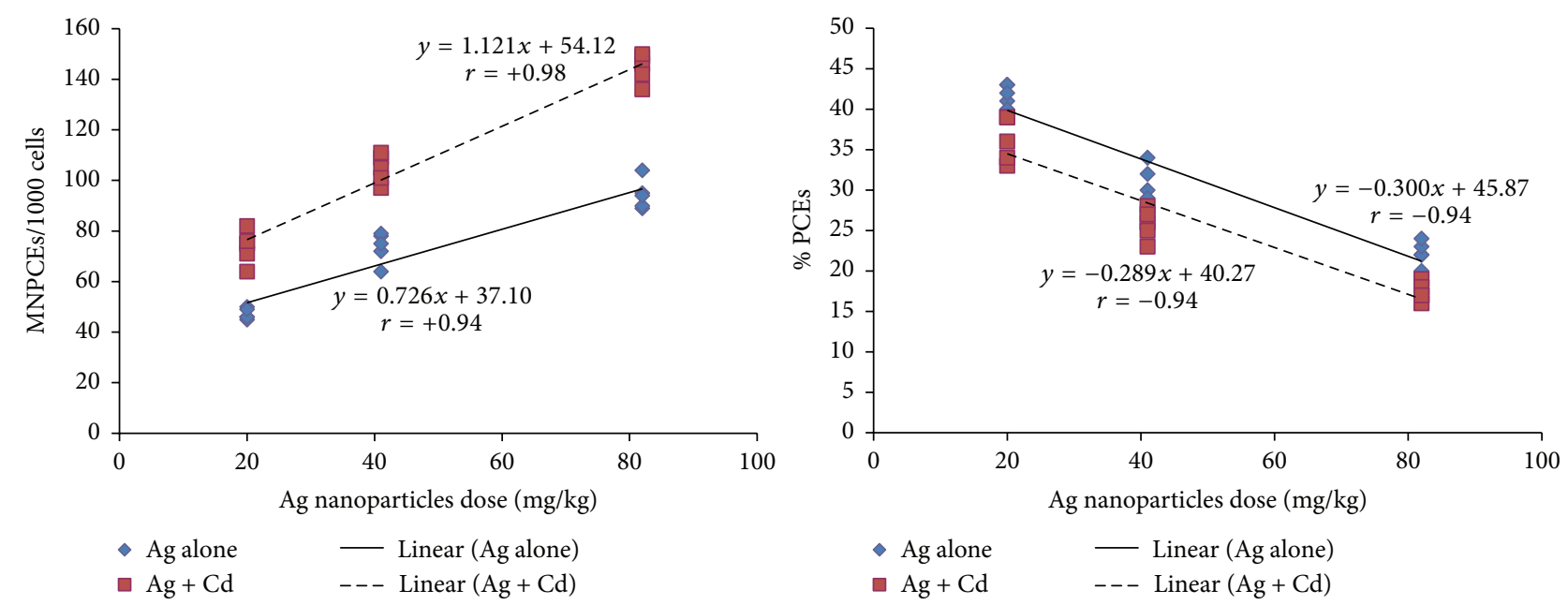

FIGURE 4: Regression lines and correlation coefficients between frequency of MNPCEs or percentage of PCEs and the different doses of Ag nanoparticles in mice injected i.p. with $\mathrm{Ag}$ nanoparticles either alone or with $\mathrm{CaCl}_{2}$.

compared with the negative control level and the cotreatment of $\mathrm{CdCl}_{2}$ with $\mathrm{Ag}$ nanoparticles different doses statistically decreased $(p<0.001) \%$ PCEs compared with Ag nanoparticles treated groups as shown in Table 3.

Both of MNPCEs and \% PCEs were statistically affected $(p<0.001)$ by the Ag nanoparticles doses in groups treated with either Ag alone $(F=149.53, F=110.01)$ or $\mathrm{CdCl}_{2}$ $(F=104.76, F=172.93)$, respectively. Strong positive and negative correlations between the $\mathrm{Ag}$ nanoparticles doses and MNPCEs and \% PCEs, respectively, were indicated by the regression analysis curves (Figure 4) in all Ag nanoparticles treated groups.

3.5. Comet Assay Results. Results of comet assay are summarized in Tables 4(a), 4(b), and 4(c) and Figure 5 that showed representative photo for the observed various grades of DNA damage regardless of organs and treatment. Groups which received single injection of either $\mathrm{CdCl}_{2}(1.5 \mathrm{mg} / \mathrm{kg})$ or $\mathrm{Ag}$ nanoparticles in different doses showed statistical significant increases $(p<0.001)$ in tail length, \% DNA in tail, and tail moment compared with the negative control group. However, $\mathrm{CdCl}_{2}$ cotreatment enhanced the $\mathrm{Ag}$ nanoparticles induced DNA damage as shown by the statistical significant increases in tail length, \% DNA in tail, and tail moment in groups injected with both $\mathrm{CdCl}_{2}$ and $\mathrm{Ag}$ nanoparticles compared with the Ag nanoparticles treated groups' levels. This DNA damage induction was statistically affected $(p<0.001)$ by the Ag nanoparticles dose as shown by one way ANOVA analysis (Tables 4(a), 4(b), and 4(c)) and regression analysis curves evidenced the strong positive correlations between DNA damage inductions and Ag nanoparticles doses in all $\mathrm{Ag}$ treated groups either alone or with $\mathrm{CdCl}_{2}$ (Figure 6).

3.6. MDA Level and CAT Activity. Single i.p. injection of either $\mathrm{CdCl}_{2}(1.5 \mathrm{mg} / \mathrm{kg})$ or $\mathrm{Ag}$ nanoparticles $(20,41$, and $82 \mathrm{mg} / \mathrm{kg})$ caused statistical significant $(p<0.001)$ elevations in the MDA level and decreases in CAT activity compared with the negative control level (Table 5). Furthermore, $\mathrm{CdCl}_{2}$ coinjected with the different doses of $\mathrm{Ag}$ nanoparticles resulted in statistical significant $(p<0.001)$ increases in 
TABLE 4: (a) Tail length, \% DNA in tail, and tail moment in bone marrow cells of mice injected i.p. with $\mathrm{Ag}_{\text {nanoparticles or/and CaCl}}$. (b) Tail length, \% DNA in tail, and tail moment in testis of mice injected i.p. with Ag nanoparticles or/and $\mathrm{CaCl}_{2}$. (c) Tail length, \% DNA in tail, and tail moment in sperms of mice injected i.p. with $\mathrm{Ag}$ nanoparticles or/and $\mathrm{CaCl}_{2}$.

(a)

\begin{tabular}{lcccc}
\hline Group & Treatment (dose $\mathrm{mg} / \mathrm{kg})$ & Tail length $(\mathrm{px})$ & \% DNA in tail & Tail moment \\
\hline 1 & Negative control $_{2}$ & $7.60 \pm 0.98$ & $16.57 \pm 1.33$ & $1.29 \pm 0.19$ \\
2 & $\mathrm{Cd}_{(1.6)}$ & $25.30 \pm 2.54^{\mathrm{a}}$ & $28.25 \pm 1.58^{\mathrm{a}}$ & $7.47 \pm 1.02^{\mathrm{a}}$ \\
3 & $\mathrm{Ag}_{(20)}$ & $15.50 \pm 1.11^{\mathrm{a}}$ & $23.03 \pm 1.94^{\mathrm{a}}$ & $3.82 \pm 0.47^{\mathrm{a}}$ \\
4 & $\mathrm{Ag}_{(41)}$ & $24.77 \pm 2.67^{\mathrm{a}}$ & $31.85 \pm 3.74^{\mathrm{a}}$ & $8.20 \pm 0.47^{\mathrm{a}}$ \\
5 & $\mathrm{Ag}_{(82)}$ & $31.62 \pm 1.80^{\mathrm{a}}$ & $43.58 \pm 2.44^{\mathrm{a}}$ & $13.64 \pm 1.01^{\mathrm{a}}$ \\
6 & $\mathrm{Ag}_{(20)}+\mathrm{Cd}$ & $26.67 \pm 2.34^{\mathrm{a}, \mathrm{b}}$ & $34.59 \pm 2.98^{\mathrm{a}, \mathrm{b}}$ & $9.17 \pm 0.72^{\mathrm{a}, \mathrm{b}}$ \\
7 & $\mathrm{Ag}_{(41)}+\mathrm{Cd}$ & $39.02 \pm 2.94^{\mathrm{a}, \mathrm{b}}$ & $46.62 \pm 1.67^{\mathrm{a}, \mathrm{b}}$ & $18.15 \pm 1.12^{\mathrm{a}, \mathrm{b}}$ \\
8 & $\mathrm{Ag}_{(82)}+\mathrm{Cd}$ & $50.02 \pm 4.88^{\mathrm{a}, \mathrm{b}}$ & $54.74 \pm 3.18^{\mathrm{a}, \mathrm{b}}$ & $27.16 \pm 2.74^{\mathrm{a}, \mathrm{b}}$ \\
\hline & Groups 3, 4 , and 5 & $F=84.4, p<0.001$ & $F=67.2, p<0.001$ & $F=194.0, p<0.001$ \\
& Groups 6, 7, and 8 & $F=53.9, p<0.001$ & $F=70.7, p<0.001$ & $F=130.7, p<0.001$ \\
\hline
\end{tabular}

Results were expressed as mean \pm SD. ${ }^{a}$ Statistically significantly different from the negative control group and ${ }^{b}$ statistically significantly different from the comparable nano-Ag treated group at $p<0.001$ using Student's $t$-test. One way ANOVA was used to test the effect of different doses of Ag nanoparticles on the tested parameters.

(b)

\begin{tabular}{lcccc}
\hline Group & Treatment $($ dose $\mathrm{mg} / \mathrm{kg})$ & Tail length $(\mathrm{px})$ & \% DNA in tail & Tail moment \\
\hline 1 & Negative control & $6.23 \pm 0.51$ & $14.14 \pm 1.06$ & $0.88 \pm 0.11$ \\
2 & $\mathrm{Cd}_{(1.6)}$ & $16.60 \pm 2.20^{\mathrm{a}}$ & $25.11 \pm 2.46^{\mathrm{a}}$ & $4.73 \pm 0.96^{\mathrm{a}}$ \\
3 & $\mathrm{Ag}_{(20)}$ & $21.29 \pm 2.41^{\mathrm{a}}$ & $22.11 \pm 1.72^{\mathrm{a}}$ & $4.85 \pm 0.99^{\mathrm{a}}$ \\
4 & $\mathrm{Ag}_{(41)}$ & $31.27 \pm 3.16^{\mathrm{a}}$ & $32.99 \pm 1.18^{\mathrm{a}}$ & $10.42 \pm 1.30^{\mathrm{a}}$ \\
5 & $\mathrm{Ag}_{(82)}$ & $45.31 \pm 0.75^{\mathrm{a}}$ & $44.79 \pm 2.64^{\mathrm{a}}$ & $20.14 \pm 1.47^{\mathrm{a}}$ \\
6 & $\mathrm{Ag}_{(20)}+\mathrm{Cd}$ & $29.29 \pm 2.04^{\mathrm{a}, \mathrm{b}}$ & $33.68 \pm 2.64^{\mathrm{a}, \mathrm{b}}$ & $9.71 \pm 0.57^{\mathrm{a}, \mathrm{b}}$ \\
7 & $\mathrm{Ag}_{(41)}+\mathrm{Cd}$ & $45.70 \pm 3.56^{\mathrm{a}, \mathrm{b}}$ & $48.45 \pm 3.50^{\mathrm{a}, \mathrm{b}}$ & $22.45 \pm 3.16^{\mathrm{a}, \mathrm{b}}$ \\
8 & $\operatorname{Ag}_{(82)}+\mathrm{Cd}$ & $63.47 \pm 3.48^{\mathrm{a}, \mathrm{b}}$ & $71.39 \pm 4.25^{\mathrm{a}, \mathrm{b}}$ & $45.14 \pm 3.03^{\mathrm{a}, \mathrm{b}}$ \\
\hline & Groups 3, 4, and 5 & $F=133.4, p<0.001$ & $F=170.4, p<0.001$ & $F=185.2, p<0.001$ \\
& Groups 6, 7, and 8 & $F=151.5, p<0.001$ & $F=145.2, p<0.001$ & $F=248.8, p<0.001$ \\
\hline
\end{tabular}

Results were expressed as mean \pm SD. ${ }^{a}$ Statistically significantly different from the negative control group and ${ }^{b}$ statistically significantly different from the comparable nano-Ag treated group at $p<0.001$ using Student's $t$-test. One way ANOVA was used to test the effect of different doses of Ag nanoparticles on the tested parameters.

(c)

\begin{tabular}{lcccc}
\hline Group & Treatment $($ dose $\mathrm{mg} / \mathrm{kg})$ & Tail length $(\mathrm{px})$ & \% DNA in tail & Tail moment \\
\hline 1 & Negative control $_{2}$ & $7.51 \pm 1.70$ & $12.33 \pm 1.33$ & $1.01 \pm 0.34$ \\
2 & $\mathrm{Cd}_{(1.6)}$ & $21.36 \pm 3.95^{\mathrm{a} * * *}$ & $25.17 \pm 1.72^{\mathrm{a} * * *}$ & $5.84 \pm 1.32^{\mathrm{a} * * *}$ \\
3 & $\operatorname{Ag}_{(20)}$ & $15.35 \pm 157^{\mathrm{a} * * *}$ & $22.44 \pm 1.67^{\mathrm{a} * * *}$ & $4.33 \pm 1.25^{\mathrm{a} * * *}$ \\
4 & $\mathrm{Ag}_{(41)}$ & $22.89 \pm 2.71^{\mathrm{a} * * *}$ & $32.84 \pm 3.53^{\mathrm{a} * * *}$ & $7.37 \pm 0.45^{\mathrm{a} * * *}$ \\
5 & $\mathrm{Ag}_{(82)}$ & $34.45 \pm 2.95^{\mathrm{a} * * *}$ & $45.64 \pm 3.09^{\mathrm{a} * * *}$ & $15.75 \pm 1.89^{\mathrm{a} * * *}$ \\
6 & $\mathrm{Ag}_{(20)}+\mathrm{Cd}$ & $23.65 \pm 4.21^{\mathrm{a} * * *, \mathrm{~b} * *}$ & $36.43 \pm 9.79^{\mathrm{a} * *, \mathrm{~b} *}$ & $7.58 \pm 1.39^{\mathrm{a} * * *, \mathrm{~b} * *}$ \\
7 & $\mathrm{Ag}_{(41)}+\mathrm{Cd}$ & $34.05 \pm 4.82^{\mathrm{a} * * *, \mathrm{~b} * *}$ & $52.32 \pm 4.15^{\mathrm{a} * *, \mathrm{~b} * * *}$ & $17.71 \pm 3.09^{\mathrm{a} * *, \mathrm{~b} * * *}$ \\
8 & $\mathrm{Ag}_{(82)}+\mathrm{Cd}$ & $54.92 \pm 4.63^{\mathrm{a} * *, \mathrm{~b} * *}$ & $73.00 \pm 4.48^{\mathrm{a} * *, \mathrm{~b} * *}$ & $37.08 \pm 9.00^{\mathrm{a} * * *, \mathrm{~b} * *}$ \\
\hline & Groups 3, 4, and 5 & $F=74.9, p<0.001$ & $F=81.6, p<0.001$ & $F=100.5, p<0.001$ \\
& Groups 6, 7, and 8 & $F=60.9, p<0.001$ & $F=173.8, p<0.001$ & $F=357.2, p<0.001$ \\
\hline
\end{tabular}

Results were expressed as mean \pm SD. ${ }^{a}$ Statistically significantly different from the negative control group and ${ }^{b}$ statistically significantly different from the comparable nano-Ag treated group at ${ }^{*} p<0.05,{ }^{* *} p<0.01$, and ${ }^{* * *} p<0.001$ using Student's $t$-test. One way ANOVA was used to test the effect of different doses of Ag nanoparticles on the tested parameters.

MDA level and decreases in CAT activity compared with Ag nanoparticles groups' values (Table 5).

One way ANOVA showed that both of MDA level and CAT activity were significantly altered by the dose of Ag nanoparticles (Table 5) and the regression analysis curves revealed the strong positive and negative correlations between Ag nanoparticles dose and MDA level and CAT activity in all Ag treated groups (Figure 7). 
TABLE 5: The MDA level and CAT activity in bone marrow, testis, and sperms of mice injected i.p. with Ag nanoparticles or/and CaCl 2 .

\begin{tabular}{|c|c|c|c|c|c|c|c|}
\hline \multirow[b]{2}{*}{ Group } & \multirow{2}{*}{$\begin{array}{c}\text { Treatment } \\
\text { (dose } \mathrm{mg} / \mathrm{kg} \text { ) }\end{array}$} & \multicolumn{2}{|c|}{ Bone marrow } & \multicolumn{2}{|c|}{ Testis } & \multicolumn{2}{|c|}{ Sperms } \\
\hline & & $\begin{array}{l}\text { MDA level } \\
(\mathrm{nmol} / \mathrm{g})\end{array}$ & $\begin{array}{c}\text { CAT activity } \\
(\mathrm{U} / \mathrm{g})\end{array}$ & $\begin{array}{l}\text { MDA level } \\
(\mathrm{nmol} / \mathrm{g})\end{array}$ & $\begin{array}{c}\text { CAT activity } \\
(\mathrm{U} / \mathrm{g})\end{array}$ & $\begin{array}{l}\text { MDA level } \\
\left(\mathrm{nmol} / 10^{6}\right)\end{array}$ & $\begin{array}{c}\text { CAT activity } \\
\left(\mathrm{U} / 10^{6}\right)\end{array}$ \\
\hline 1 & $\begin{array}{c}\text { Negative } \\
\text { control }\end{array}$ & $29.76 \pm 1.31$ & $8.15 \pm 0.52$ & $38.05 \pm 1.66$ & $7.01 \pm 0.41$ & $2.93 \pm 0.16$ & $46.83 \pm 2.36$ \\
\hline 2 & $\mathrm{Cd}_{(1.6)}$ & $49.49 \pm 1.80^{\mathrm{a}}$ & $4.21 \pm 0.62^{\mathrm{a}}$ & $57.77 \pm 4.27^{\mathrm{a}}$ & $3.24 \pm 0.29^{\mathrm{a}}$ & $9.95 \pm 0.12^{\mathrm{a}}$ & $36.09 \pm 2.33^{\mathrm{a}}$ \\
\hline 3 & $\mathrm{Ag}_{(20)}$ & $47.88 \pm 1.71^{\mathrm{a}}$ & $5.58 \pm 0.48^{\mathrm{a}}$ & $59.17 \pm 4.75^{\mathrm{a}}$ & $4.47 \pm 0.38^{\mathrm{a}}$ & $6.30 \pm 0.22^{\mathrm{a}}$ & $32.79 \pm 1.90^{\mathrm{a}}$ \\
\hline 4 & $\mathrm{Ag}_{(41)}$ & $60.52 \pm 1.12^{\mathrm{a}}$ & $4.10 \pm 0.29^{\mathrm{a}}$ & $78.04 \pm 5.72^{\mathrm{a}}$ & $2.98 \pm 0.29^{\mathrm{a}}$ & $9.45 \pm 0.12^{\mathrm{a}}$ & $26.50 \pm 2.45^{\mathrm{a}}$ \\
\hline 5 & $\mathrm{Ag}_{(82)}$ & $89.78 \pm 2.48^{\mathrm{a}}$ & $2.88 \pm 0.28^{\mathrm{a}}$ & $107.03 \pm 7.72^{\mathrm{a}}$ & $2.20 \pm 0.25^{\mathrm{a}}$ & $14.17 \pm 0.45^{\mathrm{a}}$ & $17.51 \pm 1.64^{\mathrm{a}}$ \\
\hline 6 & $\mathrm{Ag}_{(20)}+\mathrm{Cd}$ & $68.93 \pm 3.42^{\mathrm{a}, \mathrm{b}}$ & $4.04 \pm 0.37^{\mathrm{a}, \mathrm{b}}$ & $92.62 \pm 2.60^{\mathrm{a}, \mathrm{b}}$ & $2.57 \pm 0.49^{\mathrm{a}, \mathrm{b}}$ & $8.64 \pm 0.30^{\mathrm{a}, \mathrm{b}}$ & $24.37 \pm 1.82^{\mathrm{a}, \mathrm{b}}$ \\
\hline 7 & $\mathrm{Ag}_{(41)}+\mathrm{Cd}$ & $87.93 \pm 1.36^{\mathrm{a}, \mathrm{b}}$ & $2.95 \pm 0.32^{\mathrm{a}, \mathrm{b}}$ & $116.55 \pm 3.44^{\mathrm{a}, \mathrm{b}}$ & $1.95 \pm 0.15^{\mathrm{a}, \mathrm{b}}$ & $12.40 \pm 0.44^{\mathrm{a}, \mathrm{b}}$ & $13.11 \pm 2.19^{\mathrm{a}, \mathrm{b}}$ \\
\hline 8 & $\mathrm{Ag}_{(82)}+\mathrm{Cd}$ & $116.68 \pm 5.82^{\mathrm{a}, \mathrm{b}}$ & $1.99 \pm 0.08^{\mathrm{a}, \mathrm{b}}$ & $133.43 \pm 2.02^{\mathrm{a}, \mathrm{b}}$ & $1.12 \pm 0.16^{\mathrm{a}, \mathrm{b}}$ & $21.22 \pm 2.79^{\mathrm{a}, \mathrm{b}}$ & $6.86 \pm 0.74^{\mathrm{a}, \mathrm{b}}$ \\
\hline \multicolumn{2}{|c|}{ Groups 3,4 , and 5} & $\begin{array}{c}F=1088.7 \\
p<0.001\end{array}$ & $\begin{array}{l}F=69.7 \\
p<0.001\end{array}$ & $\begin{array}{l}F=682.8 \\
p<0.001\end{array}$ & $\begin{array}{l}F=67.7 \\
p<0.001\end{array}$ & $\begin{array}{l}F=879.1 \\
p<0.001\end{array}$ & $\begin{array}{l}F=71.8 \\
p<0.001\end{array}$ \\
\hline \multicolumn{2}{|c|}{ Groups 6,7 , and 8} & $\begin{array}{l}F=732.3 \\
p<0.001\end{array}$ & $\begin{array}{l}F=64.2 \\
p<0.001\end{array}$ & $\begin{array}{l}F=277.9 \\
p<0.001\end{array}$ & $\begin{array}{l}F=27.7 \\
p<0.001\end{array}$ & $\begin{array}{c}F=689.8 \\
p<0.001\end{array}$ & $\begin{array}{l}F=136.4 \\
p<0.001\end{array}$ \\
\hline
\end{tabular}

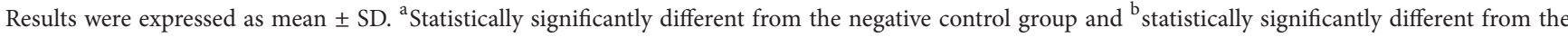
comparable nano-Ag treated group at $p<0.001$ using Student's $t$-test. One way ANOVA was used to test the effect of different doses of Ag nanoparticles on the tested parameters.

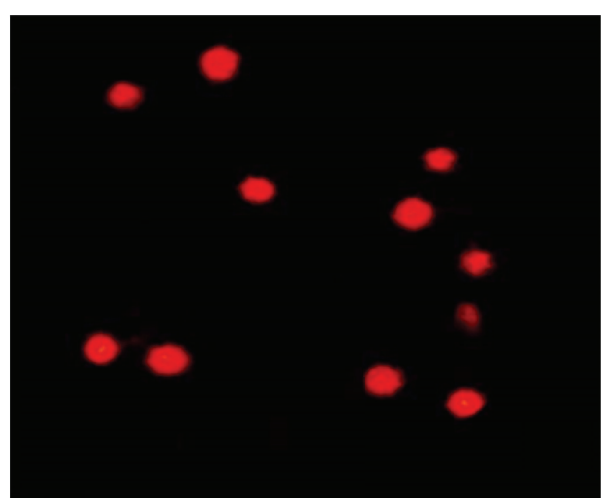

(a)

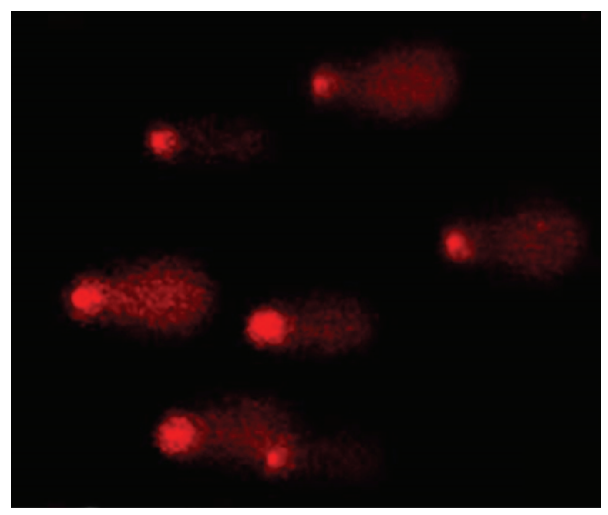

(c)

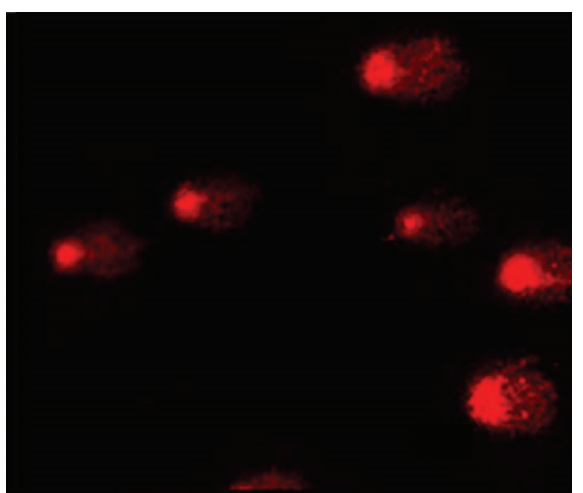

(b)

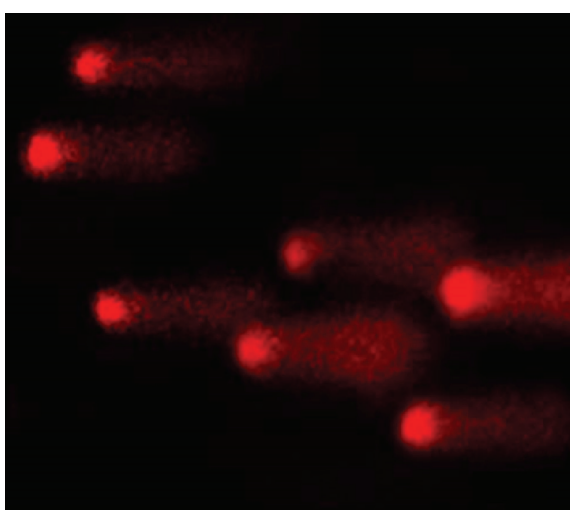

(d)

FIGURE 5: Representative photos for the observed various grades of DNA damage (b-d) and undamaged DNA (a).

\section{Discussion}

The incredible rapid growth in the uses and applications of Ag nanoparticles because of their antimicrobial properties increases human exposure to them. On the other hand, increasing environmental pollution increases human exposure to many other pollutants including heavy metals, for example, $\mathrm{Cd}$ in addition to $\mathrm{Ag}$ nanoparticles via various ways including contaminated water, fishes, and other sources. Therefore, it is essential to investigate the effect of $\mathrm{Cd}$ on the $\mathrm{Ag}$ nanoparticles induced genomic instability and DNA damage in mice testis, sperms, and bone marrow cells in this study. 

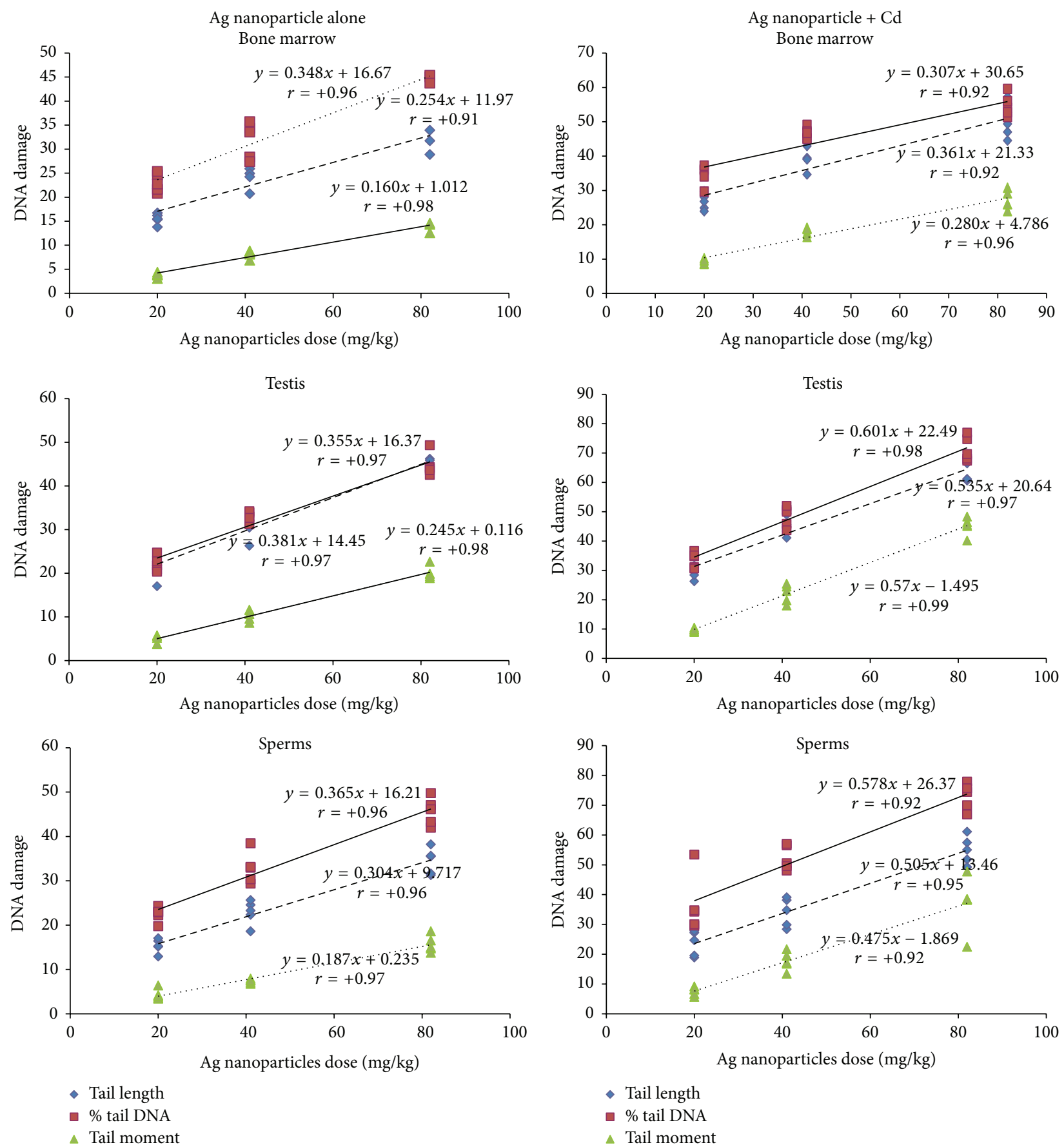

FiguRE 6: Regression lines and correlation coefficients between tail length, \% DNA in tail, or tail moment and the different doses of Ag nanoparticles in mice injected i.p. with $\mathrm{Ag}$ nanoparticles either alone or with $\mathrm{CaCl}_{2}$.

The observed significant elevations in sperm abnormality, MNPCEs frequencies, and DNA damage inductions and significant decreases in \% PCEs compared with the negative control group in this study confirmed the previously reported cyto-, clasto-, and genotoxic effects of Cd [30, 36-38]. This genotoxic effect of $\mathrm{Cd}$ could be attributed to its capacity to stimulate oxidative stress by interacting with the thiol groups of antioxidant enzyme and thus inhibiting them as revealed in our study by the significant elevations in MDA level and reduced CAT activity in Cd treated group.

First our results confirmed the dose-dependent genotoxicity of Ag nanoparticles alone on both chromosomal and DNA levels by the significant elevations in micronuclei frequencies and DNA damage parameters in agreement with the previous studies [39-41]. Indeed, our finding of reproductive function deterioration in Ag nanoparticles treated male 

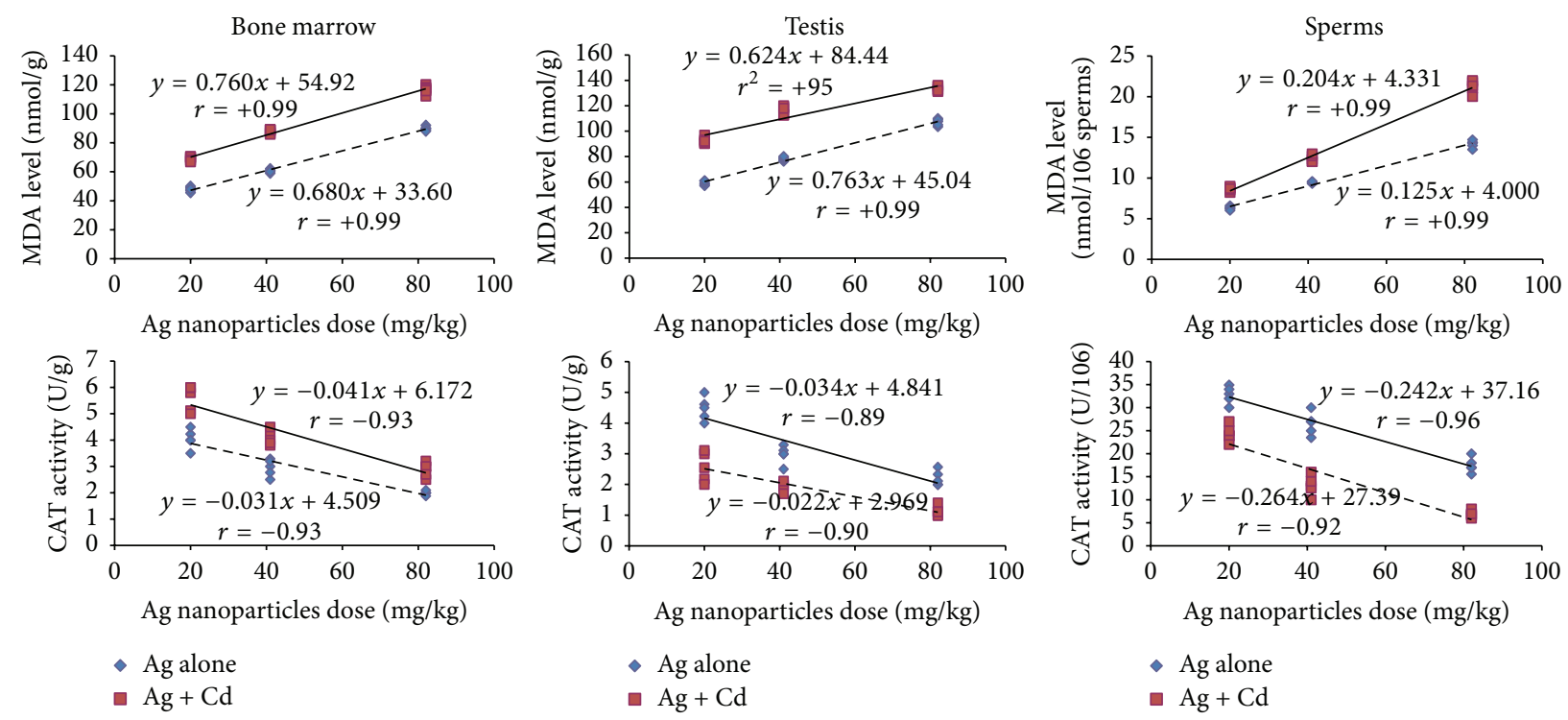

FIGURE 7: Regression lines and correlation coefficients between MDA level or CAT activity and the different doses of Ag nanoparticles in mice injected i.p. with Ag nanoparticles either alone or with $\mathrm{CaCl}_{2}$.

mice by decreased sperm production and increased sperm abnormalities is in consistence with the previously reported impairment of sperm stability in Ag nanoparticles treated mice [24]. Hence, sperm abnormalities could be attributed to the observed nano-Ag induced chromosomal aberrations and DNA damage occurring during the packaging of genetic material in the sperms in addition to other possible genetic causes such as small deletions, point mutations, and mistakes in the spermatozoa-differentiating process during spermatogenesis.

Recently, Ag nanoparticles have been shown to damage DNA directly through the reaction of $\mathrm{Ag}+$ ions released by Ag nanoparticles leading to reactive oxygen species (ROS) productions [41-43]. The ROS generation is considered as a key role in nano-Ag induced genotoxicity as increased ROS production decreases the cellular antioxidant defenses and disrupts the mitochondrial function by reacting with critical cellular molecules, such as lipids, proteins, nucleic acids, and carbohydrates, and generating additional radicals in a chain of reaction known as lipid peroxidation. In this study the dose-dependent significant elevations in MDA level and decreases in the antioxidant CAT activity revealed the ROS productions by Ag nanoparticles in accordance with previous studies that suggested oxidative stress induction as a possible mechanism for Ag nanoparticles induced genotoxicity [41, $44,45]$.

On the other hand, $\mathrm{Cd}$ coadministration with $\mathrm{Ag}$ nanoparticles in different doses significantly increased the sperm abnormality, chromosomal damage, and DNA damage inductions levels compared with the Ag nanoparticles alone treated groups. Potentiating Ag nanoparticles induced toxicity could be attributed to the observed significant increases in MDA level and decreases in CAT activity revealing increased ROS generations and oxidative stress inductions by Ag nanoparticles after $\mathrm{Cd}$ coadministration. The ability of $\mathrm{Cd}$ ions to replace copper and iron in various cytoplasmic and membrane proteins including ferritin and apoferritin resulting in elevations in the amount of free copper and iron ions that induces oxidative stress in addition to ROS mediated oxidative stress inductions by Ag+ ions thereby enhanced and potentiated the DNA damage inductions by Ag nanoparticles [41, 46-48]. Indeed, the observed significant elevations in MDA level and decreases in the CAT activity in Cd treated group revealed the oxidative stress inductions by $\mathrm{Cd}$ via inhibitions of the antioxidant defense system as previously mentioned in various studies [49-53].

Consequently, the observed significant elevations in $\mathrm{Ag}$ nanoparticles induced genotoxicity after Cd coadministration supported the previously reported cogenotoxic effects of $\mathrm{Cd}$ when combined with other mutagenic agents including UV-radiation, methyl methanesulfonate (MMS), and $\mathrm{N}$ methyl-N-nitrosourea (MNU) [54]. Based on our data the presence of heavy metal cadmium chloride weakened cells, decreased their resistance, and increased their sensitivity to Ag nanoparticles induced chromosomal and DNA damage and thereby potentiated nano-Ag particles induced genotoxicity and increased their severity and risk.

\section{Conclusion}

The observed Ag nanoparticles induced dose-dependent sperm abnormality, clastogenicity, and genotoxicity in this study were potentiated by Cd coadministration. Indeed, Ag nanoparticles induced toxicities were strongly correlated with significant elevations in MDA level and decreases in CAT activity confirmed the consideration of oxidative stress as a possible mechanism for Ag nanoparticles induced genotoxicity.

\section{Competing Interests}

The author declares that there are no competing interests. 


\section{References}

[1] P. L. Drake and K. J. Hazelwood, "Exposure-related health effects of silver and silver compounds: a review," The Annals of Occupational Hygiene, vol. 49, no. 7, pp. 575-585, 2005.

[2] V. Edwards-Jones, “The benefits of silver in hygiene, personal care and healthcare," Letters in Applied Microbiology, vol. 49, no. 2, pp. 147-152, 2009.

[3] C. Elliott, "The effects of silver dressings on chronic and burns wound healing," British Journal of Nursing, vol. 19, no. 15, pp. S32-S36, 2010.

[4] J. H. Lee, J. D. Chae, D. G. Kim, S. H. Hong, W. M. Lee, and M. $\mathrm{Ki}$, "Comparison of the efficacies of silver-containing dressing materials for treating a full-thickness rodent wound infected by methicillin-resistant Staphylococcus aureus," Korean Journal of Laboratory Medicine, vol. 30, no. 1, pp. 20-27, 2010.

[5] Y. S. Kim, J. S. Kim, H. S. Cho et al., "Twenty-eight-day oral toxicity, genotoxicity, and gender-related tissue distribution of silver nanoparticles in Sprague-Dawley rats," Inhalation Toxicology, vol. 20, no. 6, pp. 575-583, 2008.

[6] J. Tang, L. Xiong, S. Wang et al., "Distribution, translocation and accumulation of silver nanoparticles in rats," Journal of Nanoscience and Nanotechnology, vol. 9, no. 8, pp. 4924-4932, 2009.

[7] E.-J. Park, E. Bae, J. Yi et al., "Repeated-dose toxicity and inflammatory responses in mice by oral administration of silver nanoparticles," Environmental Toxicology and Pharmacology, vol. 30, no. 2, pp. 162-168, 2010.

[8] Y.-H. Hsin, C.-F. Chen, S. Huang, T.-S. Shih, P.-S. Lai, and P. J. Chueh, "The apoptotic effect of nanosilver is mediated by a ROS- and JNK-dependent mechanism involving the mitochondrial pathway in NIH3T3 cells," Toxicology Letters, vol. 179, no. 3, pp. 130-139, 2008.

[9] Y. Wu, Q. Zhou, H. Li, W. Liu, T. Wang, and G. Jiang, "Effects of silver nanoparticles on the development and histopathology biomarkers of Japanese medaka (Oryzias latipes) using the partial-life test," Aquatic Toxicology, vol. 100, no. 2, pp. 160-167, 2010.

[10] R. Foldbjerg, D. A. Dang, and H. Autrup, "Cytotoxicity and genotoxicity of silver nanoparticles in the human lung cancer cell line, A549," Archives of Toxicology, vol. 85, no. 7, pp. 743750, 2011.

[11] M. E. Samberg, S. J. Oldenburg, and N. A. Monteiro-Riviere, "Evaluation of silver nanoparticle toxicity in skin in vivo and keratinocytes in vitro," Environmental Health Perspectives, vol. 118, no. 3, pp. 407-413, 2010.

[12] J. P. Wise Sr., B. C. Goodale, S. S. Wise et al., "Silver nanospheres are cytotoxic and genotoxic to fish cells," Aquatic Toxicology, vol. 97, no. 1, pp. 34-41, 2010.

[13] N. Miura and Y. Shinohara, "Cytotoxic effect and apoptosis induction by silver nanoparticles in HeLa cells," Biochemical and Biophysical Research Communications, vol. 390, no. 3, pp. 733-737, 2009.

[14] H. Bouwmeester, J. Poortman, R. J. Peters et al., "Characterization of translocation of silver nanoparticles and effects on whole-genome gene expression using an in vitro intestinal epithelium coculture model," ACS Nano, vol. 5, no. 5, pp. 40914103, 2011.

[15] A. Patlolla, K. Hackett D, and P. Tchounwou, "Oral presentation 11: genotoxicity study of silver nanoparticles in bone marrow cells of Sprague-Dawley rats," in Proceedings of the 7th International Symposium on Recent Advances in Environmental Health Research, Jackson, Miss, USA, September 2010.

[16] C. G. Ordzhonikidze, L. K. Ramaiyya, E. M. Egorova, and A. V. Rubanovich, "Genotoxic effects of silver nanoparticles on mice in vivo," Acta Naturae, vol. 1, no. 3, pp. 99-101, 2009.

[17] D. K. Tiwari, T. Jin, and J. Behari, "Dose-dependent in-vivo toxicity assessment of silver nanoparticle in Wistar rats," Toxicology Mechanisms and Methods, vol. 21, no. 1, pp. 13-24, 2011.

[18] J. E. Choi, S. Kim, J. H. Ahn et al., "Induction of oxidative stress and apoptosis by silver nanoparticles in the liver of adult zebrafish," Aquatic Toxicology, vol. 100, no. 2, pp. 151-159, 2010.

[19] M. Ahamed, R. Posgai, T. J. Gorey, M. Nielsen, S. M. Hussain, and J. J. Rowe, "Silver nanoparticles induced heat shock protein 70, oxidative stress and apoptosis in Drosophila melanogaster," Toxicology and Applied Pharmacology, vol. 242, no. 3, pp. 263269, 2010.

[20] P. V. Asharani, Y. L. Wu, Z. Gong, and S. Valiyaveettil, “Toxicity of silver nanoparticles in zebra fish models," Nanotechnology, vol. 19, no. 25, Article ID 255102, 2008.

[21] G. Laban, L. F. Nies, R. F. Turco, J. W. Bickham, and M. S. Sepúlveda, "The effects of silver nanoparticles on fathead minnow (Pimephales promelas) embryos," Ecotoxicology, vol. 19, no. 1, pp. 185-195, 2010.

[22] P.-W. Li, T.-H. Kuo, J.-H. Chang, J.-M. Yeh, and W.-H. Chan, "Induction of cytotoxicity and apoptosis in mouse blastocysts by silver nanoparticles," Toxicology Letters, vol. 197, no. 2, pp. 82-87, 2010.

[23] N. A. Philbrook, L. M. Winn, A. R. M. N. Afrooz, N. B. Saleh, and V. K. Walker, "The effect of $\mathrm{TiO}_{2}$ and $\mathrm{Ag}$ nanoparticles on reproduction and development of Drosophila melanogaster and CD-1 mice," Toxicology and Applied Pharmacology, vol. 257, no. 3, pp. 429-436, 2011.

[24] A. A. Attia, "Evaluation of the testicular alterations induced by silver nanoparticles in male mice: biochemical, histological and ultrastructural studies," Research Journal of Pharmaceutical, Biological and Chemical Sciences, no. 4, pp. 1558-1589, 2014.

[25] J. Gromadzka-Ostrowska, K. Dziendzikowska, A. Lankoff et al., "Silver nanoparticles effects on epididymal sperm in rats," Toxicology Letters, vol. 214, no. 3, pp. 251-258, 2012.

[26] J. F. Robinson, X. Yu, E. G. Moreira, S. Hong, and E. M. Faustman, "Arsenic- and cadmium-induced toxicogenomic response in mouse embryos undergoing neurulation," Toxicology and Applied Pharmacology, vol. 250, no. 2, pp. 117-129, 2011.

[27] A. Çelik, B. Büyükakilli, B. Çimen, B. Taşdelen, M. I. Öztürk, and D. Eke, "Assessment of cadmium genotoxicity in peripheral blood and bone marrow tissues of male Wistar rats," Toxicology Mechanisms and Methods, vol. 19, no. 2, pp. 135-140, 2009.

[28] S. Cambier, P. Gonzalez, G. Durrieu, and J.-P. Bourdineaud, "Cadmium-induced genotoxicity in zebrafish at environmentally relevant doses," Ecotoxicology and Environmental Safety, vol. 73, no. 3, pp. 312-319, 2010.

[29] K. S. Abrahim, N. B. Abdel-Gawad, A. M. Mahmoud, M. M. ElGowaily, A. M. Emara, and M. M. Hwaihy, "Genotoxic effect of occupational exposure to cadmium," Toxicology and Industrial Health, vol. 27, no. 2, pp. 173-179, 2011.

[30] T. H. Ali, "Determination of the lethal dose 50\% (LD50) of cadmium chloride and the histopathological changes in male mice liver and kidneys," Journal of Education and Science, vol. 25, no. 3, pp. 27-38, 2012. 
[31] T. Watanabe and A. Endo, "Effects of selenium deficiency on sperm morphology and spermatocyte chromosomes in mice," Mutation Research Letters, vol. 262, no. 2, pp. 93-99, 1991.

[32] W. Schmid, “The micronucleus test," Mutation Research, vol. 31, no. 1, pp. 9-15, 1975.

[33] R. R. Tice, E. Agurell, D. Anderson et al., "Single cell gel/comet assay: guidelines for in vitro and in vivo genetic toxicology testing," Environmental and Molecular Mutagenesis, vol. 35, no. 3, pp. 206-221, 2000.

[34] H. Ohkawa, N. Ohishi, and K. Yagi, "Assay for lipid peroxides in animal tissues by thiobarbituric acid reaction," Analytical Biochemistry, vol. 95, no. 2, pp. 351-358, 1979.

[35] H. Aebi, "[13] Catalase in vitro," Methods in Enzymology, vol. 105, pp. 121-126, 1984.

[36] U. R. Acharya, S. S. Das, and M. Mishra, "Role of vitamin C and E on sperm abnormality and sperm count in Cadmium treated Swiss mice," Cytologia, vol. 67, no. 1, pp. 47-52, 2002.

[37] L. Ivanoviene, I. Sadauskiene, V. Lesauskaite, R. Stapuloinis, and L. Ivanov, "Induction of apoptosis by cadmium chloride in mouse liver," Biologija, vol. 2, pp. 42-45, 2004.

[38] N. Argüelles-Velázquez, I. Alvarez-González, E. MadrigalBujaidar, and G. Chamorro-Cevallos, "Amelioration of cadmium-produced teratogenicity and genotoxicity in mice given Arthrospira maxima (Spirulina) treatment," EvidenceBased Complementary and Alternative Medicine, vol. 2013, Article ID 604535, 8 pages, 2013.

[39] H. Cho, J. Sung, K. Song et al., "Genotoxicity of silver nanoparticles in lung cells of sprague dawley rats after 12 weeks of inhalation exposure," Toxics, vol. 1, no. 1, pp. 36-45, 2013.

[40] Y. Li, J. A. Bhalli, W. Ding et al., "Cytotoxicity and genotoxicity assessment of silver nanoparticles in mouse," Nanotoxicology, vol. 8, supplement 1, pp. 36-45, 2014.

[41] M. M. El Mahdy, T. A. Salah Eldin, H. S. Aly, F. F. Mohammed, and M. I. Shaalan, "Evaluation of hepatotoxic and genotoxic potential of silvernanoparticles in albino rats," Experimental and Toxicologic Pathology, vol. 67, no. 1, pp. 21-29, 2014.

[42] W. Yang, C. Shen, Q. Ji et al., "Food storage material silver nanoparticles interfere with DNA replication fidelity and bind with DNA," Nanotechnology, vol. 20, no. 8, Article ID 085102, 2009.

[43] N. Asare, C. Instanes, W. J. Sandberg et al., "Cytotoxic and genotoxic effects of silver nanoparticles in testicular cells," Toxicology, vol. 291, no. 1-3, pp. 65-72, 2012.

[44] M. M. El-Tohamy, "The mechanisms by which oxidative stress and free radical damage produces male infertility," Life Science Journal, vol. 9, no. 1, pp. 674-688, 2012.

[45] O. S. Adeyemi and T. O. Faniyan, "Antioxidant status of rats administered silver nanoparticles orally," Journal of Taibah University Medical Sciences, vol. 9, no. 3, pp. 182-186, 2014.

[46] E. Casalino, C. Sblano, and C. Landriscina, "Enzyme activity alteration by cadmium administration to rats: the possibility of iron involvement in lipid peroxidation," Archives of Biochemistry and Biophysics, vol. 346, no. 2, pp. 171-179, 1997.

[47] J.-M. Yang, M. Arnush, Q.-Y. Chen, X.-D. Wu, B. Pang, and X.Z. Jiang, "Cadmium-induced damage to primary cultures of rat Leydig cells," Reproductive Toxicology, vol. 17, no. 5, pp. 553-560, 2003.

[48] J. Y. Park and Y. R. Seo, "The protective role of Nrf2 in cadmiuminduced DNA damage," Molecular and Cellular Toxicology, vol. 7, no. 1, pp. 61-66, 2011.
[49] E. Beytut, A. Yuce, N. N. Kamiloglu, and M. Aksakal, "Role of dietary vitamin $\mathrm{E}$ in cadmium-induced oxidative damage in rabbit's blood, liver and kidneys," International Journal for Vitamin and Nutrition Research, vol. 73, no. 5, pp. 351-355, 2003.

[50] L. M. Latinwo, V. L. Badisa, C. O. Ikediobi, C. O. Odewumi, A.T. T. Lambert, and R. B. Badisa, "Effect of cadmium-induced oxidative stress on antioxidative enzymes in mitochondria and cytoplasm of CRL-1439 rat liver cells," International Journal of Molecular Medicine, vol. 18, no. 3, pp. 477-481, 2006.

[51] J. Liu, S. Y. Qian, Q. Guo et al., "Cadmium generates reactive oxygen- and carbon-centered radical species in rats: insights from in vivo spin-trapping studies," Free Radical Biology and Medicine, vol. 45, no. 4, pp. 475-481, 2008.

[52] J. Liu, W. Qu, and M. B. Kadiiska, "Role of oxidative stress in cadmium toxicity and carcinogenesis," Toxicology and Applied Pharmacology, vol. 238, no. 3, pp. 209-214, 2009.

[53] P. Koedrith and Y. R. Seo, "Advances in carcinogenic metal toxicity and potential molecular markers," International Journal of Molecular Sciences, vol. 12, no. 12, pp. 9576-9595, 2011.

[54] T. Fatur, T. T. Lah, and M. Filipič, "Cadmium inhibits repair of $\mathrm{UV}$-, methyl methanesulfonate- and $\mathrm{N}$-methyl- $\mathrm{N}$-nitrosoureainduced DNA damage in Chinese hamster ovary cells," Mutation Research/Fundamental and Molecular Mechanisms of Mutagenesis, vol. 529, no. 1-2, pp. 109-116, 2003. 

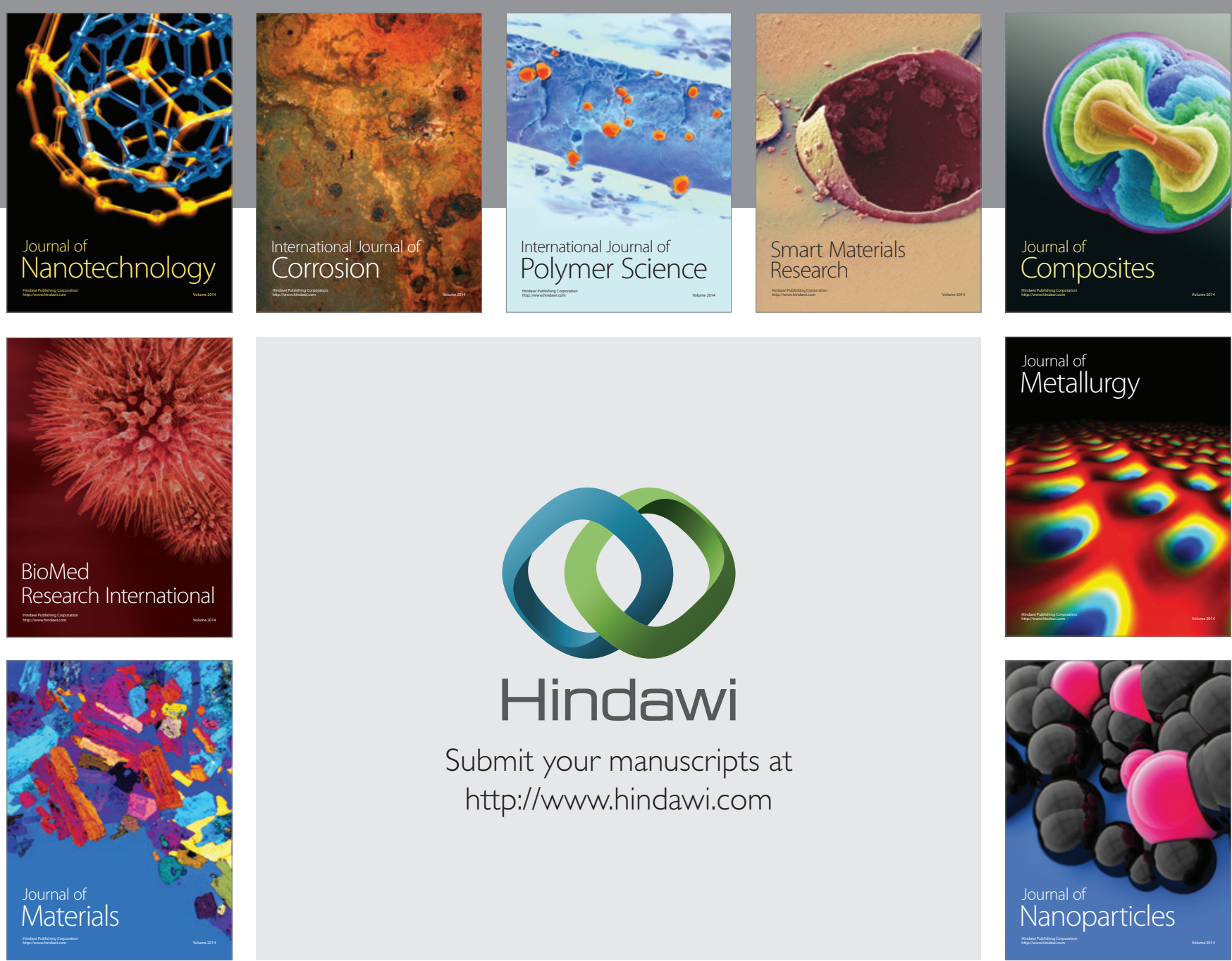

\section{Hindawi}

Submit your manuscripts at

http://www.hindawi.com

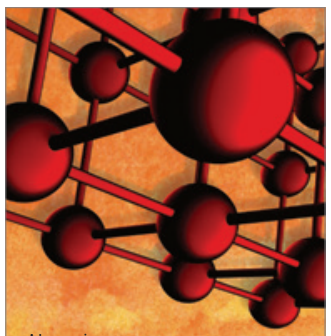

Materials Science and Engineering
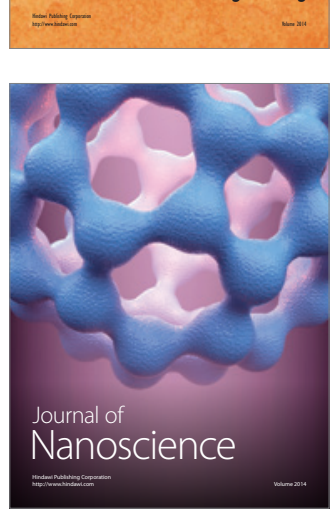
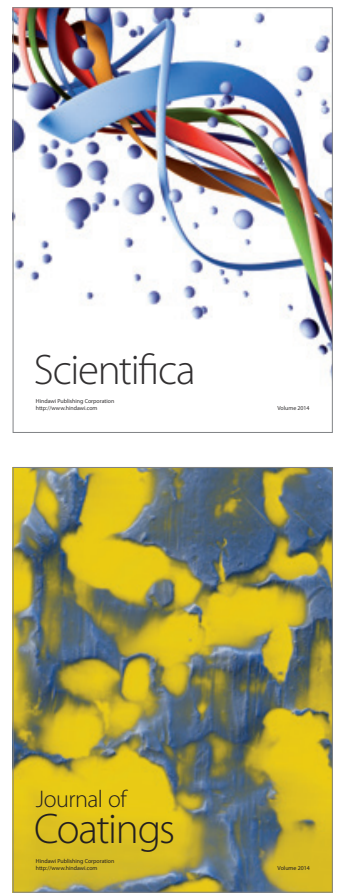
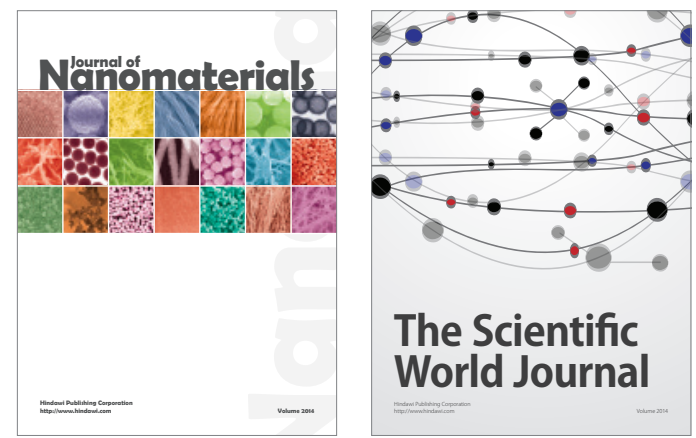

The Scientific World Journal
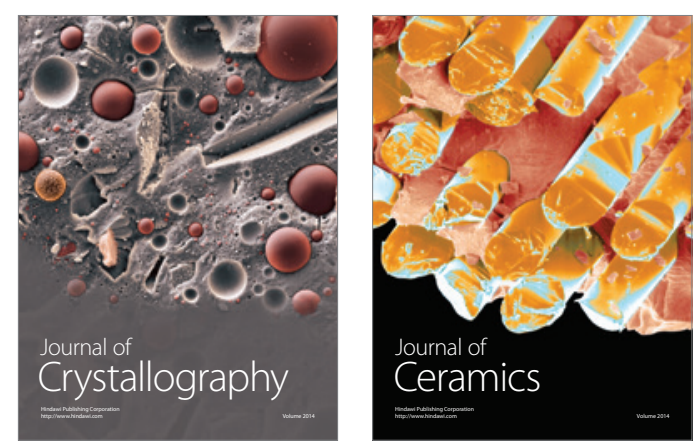
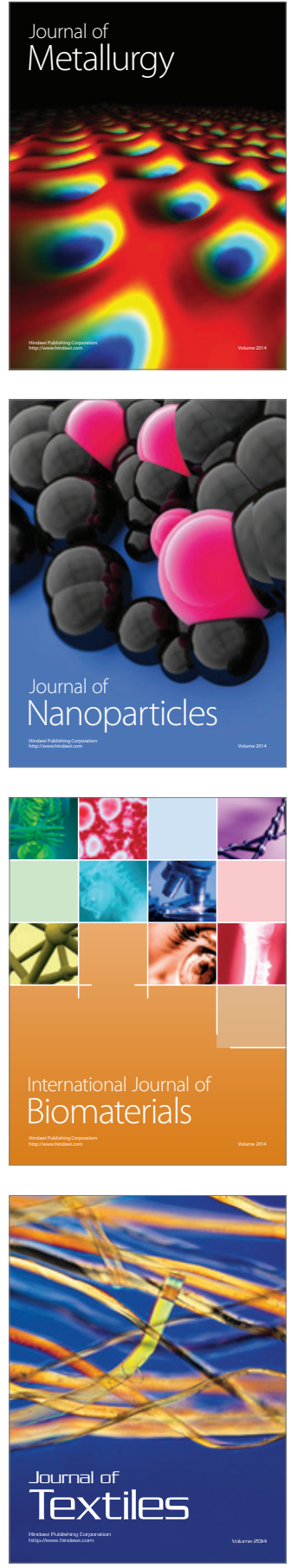